石油技術協会誌 第 67 巻 第 6 号 (平成14年11月)

JOURNAL OF THE JAPANESE ASSOCIATION FOR PETROLEUM TECHNOLOGY

VOL. 67 , NO. 6 (Nov., 2002)

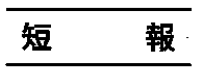

日本近海の長尺ピストンコアに見いだされたスープ状擾乱層*

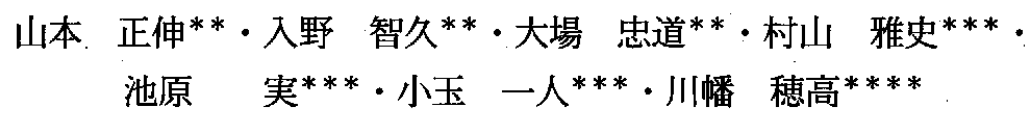

(Received September 17, 2002 ; accepted January 10, 2003)

\title{
Occurrence of soupy disturbance in long piston cores from marginal seas of the Japanese Islands
}

\begin{abstract}
Masanobu Yamamoto, Tomohisa Irino, Tadamichi Oba, Masafumi Murayama, Minoru Ikehara, Kazuto Kodama and Hodaka Kawahata
\end{abstract}

\begin{abstract}
Soupy disturbances appeared in the long piston cores taken from the Oki Ridge, off Shiretoko, off Kashima and off Kochi during IMAGES VII-WEPAMA Leg 2 (May-June2001). The soupy disturbance layers were cold when the core was recovered, and they expelled the mixture of gas, water and mud through drilled holes of the core liner tube. This suggests the dissociation of gas hydrates in the core onboard. Because the presence of soupy disturbance does not prove the existence of gas hydrate by itself, we need to obtain additional evidences in a future long piston coring study.
\end{abstract}

Key words : soupy disturbance, gas hydrate, Japan margin, long piston coring

\section{1.はじめに}

International Marine Global Change Study (IMAGES ; 海洋環境変化に関する国際共同研究)の一 環として, 2001年 5 月27日〜 6 月18日の間, IMAGES VII-WEPAMA (West Pacific Margin) 第 2 次航海が, フランスの研究船 Marion Dufresne 号をチャーターし て行われた。当航海では, 日本近海の7サイトから, 長 尺ピストンコアラーを用いて長さ $33 \sim 58 \mathrm{~m}$ のコア試料 が採取された。これらのコアの多くで,ガスハイドレー

* 平成14年 5 月 30 日, 平成 14 年度石油技術協会春李詇演会個 人講演にて一部を講演 This paper was partly presented at the 2002 JAPT Technical Meeting held in Akita, Japan, May 30, 2002.

**北海道大学大学院地球環境科学研究科 Graduate School of Environmental Earth Science, Hokkaido University

**高知大学海洋コア研究センター Marine Core Research Center, Kochi University

* 産業技術総合研究所海洋資源環境研究部門 Institute of Marine Resources and Environment, National Institute of Advanced Industrial Science and Technology

Copyright (C) 2002, JAPT
トの分解によりできたと考えられるスープ状擾乱層 (Soupy disturbance) が認められた。本報では，この スープ状摄乱層の産状を報告する。

\section{2. コアリング地点}

WEPAMA 第 2 次航海では日本列島近海加ら隠岐海 嶺, 秋田沖, 下北沖; 知床半島沖, 鹿島沖, 四国沖 2 芰 イトの計 7 サイトにおいてコアリングが行われた（Fig. 1)。コアリング地点の水深は $806 \mathrm{~m}$ 加ら $2,737 \mathrm{~m}$ にわ たる (Table 1)。いずれの地点であ岩質は粘土〜砂質シ ルトを主体とし，火山灰を挟む。堆積速度は地点により $9 \sim 106 \mathrm{~cm} / \mathrm{ky}$ と大きく異なるが，コア最上部は完新世 の堆積物加らなる（村山ほか, 1991 ; Oba et al., 1991 ; 大場・安田, 1992 ; 奥村ほか, 1996 ; 村山ほ加, 1999 ； 大場ほか，1999；島田ほか，2000）。

\section{3. スープ状擾乱層の産状}

隠岐海嶺, 知床半島沖, 鹿島沖, 四国沖においてスー プ状揌乱首が認められた (Table 1)。このスープ状摄乱 層では堆積物は完全に液状化し, 摄乱した堆積構造を示 


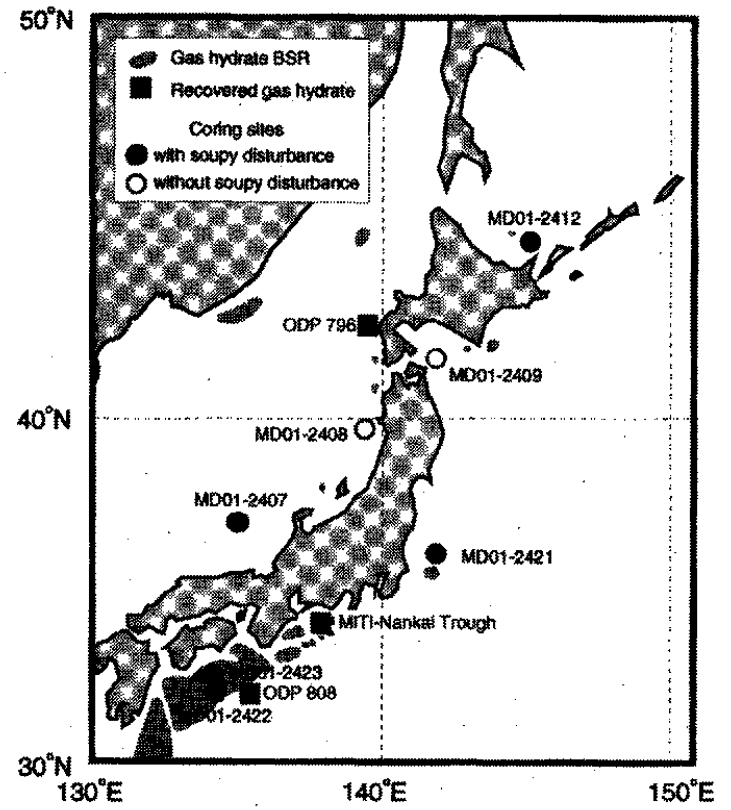

Fig. 1 Map showing the distributions of recovered gas hydrate (solid square) and gas hydrate BSR (hatched area) (After Satoh, 2001) and the locations of coring sites during IMAGES VII-WEPAMA Leg 2. Solid circle indicates the presence of soupy disturbance. Open circle indicates the absence of soupy disturbance.

す (Fig. 2)。これらの地点のコアでは，コアリング終了 直後, 甲板上でガス抜きのためコアライナー（柱状堆積 物を格納している塩化ビニル製インナーチューブ）にド リルで孔をあけた際に，泥水がガスととあに噴出した。 この噴出は間歇的に生じたことすあった。この泥水とガ スの噴出する層準では, ライナーの温度が低下し，ライ ナ一表面に水滴が凝縮した。この泥水・ガスの噴出した
層準とスープ状擾乱層の層準は一致した。

Fig. 3 にスープ状擾乱層の産状を取りまとめた。スー プ状摄乱首は, $9 \mathrm{~m}$ 以深に出現し， $20 \mathrm{~m}$ 以深に多く出 現した。スープ状擾乱層の岩質については, 鹿島沖では 火山灰，凝兏質砂，凝戻質シル卜筫粘土からなり，シル 卜質粘土む砂を多く含むあのであり，スープ状摄乱層で はない首準の岩質よりる一般に粗粒である。高知沖 MD 01-2422 ではシルト質粘土からなるが，直上に薄いパミ 不質火山灰を挟む。これに対して，知床沖では， 1 層準 が火山灰であるほかは，シルト質粘土からなり，スープ 状擾乱層ではない層準との違いはあまりない。嬡岐海嶺 コアす，シルト質粘土からなり，スープ状擾乱層ではな い首準と岩質に違いはない。このように，スープ状損乱 層と岩質との関係はサイトにより異なる。

採取されたコアには乾いたガスボイドあ認められた。 スープ状挸乱層の見られるコアはこのガスボイドも多く 含む (Fig. 3)。コアリング後にガスの遊離に伴いコア内 部の圧力が高まり，堆積物がライナー中でスライド移動 し，ガスボイドが形成されたと考えられる。

\section{4. 液状化㢖の成因}

堆積物の泥水化の原因として，コアリング時の海水と 堆積物の流れ込みによる可能性がまず考えられる。ピス トンコアリングにおいては，コア最下部にフローインと 呼ばれる堆積物の流れ込みにより擾乱した堆積構造がみ られることがある。またコア上部はピストンの負圧によ り堆積物が鉛直方向に引き伸ばされ，堆積構造が擾乱す ることがある。鹿島沖コア MD01-2421 では最上部 $8 \mathrm{~m}$ が引き伸ばされており，最下部の $4 \mathrm{~m}$ が擾乱している ことが CT スキャン画像の解析（村山, 私信）と古地磁 気測定（林田，私信）により明らかになっている。しか し，深度 8〜 42 m の層準ではコアリングによる擾乱構 造や古地磁気特性の乱れは認められず，スープ状損乱層

Table 1 Locations of coring sites, lithology, and the occurrence of soupy disturbance.

\begin{tabular}{|c|c|c|c|c|c|c|c|c|}
\hline \multicolumn{9}{|c|}{ Water depth Core length LSR } \\
\hline Core number & Latitude $(\mathrm{N})$ & Longitude(E) & Location & $(\mathrm{m})$ & (m) & $(\mathrm{cm} / \mathrm{ky})$ & Lithology & Soupy disturbance \\
\hline MD01-2407 & $37^{\circ} 04.01^{\prime}$ & $134^{\circ} 42.18^{\prime}$ & Oki Ridge & 932 & 55.28 & $g^{(a)}$ & Clay $^{(a)}$ & Present \\
\hline $\mathrm{MD} 01-2408$ & $39^{\circ} 34.41^{\prime}$ & $139^{\circ} 24.38^{\prime}$ & off Akita & 806 & 33.38 & $16^{(\mathrm{b})}$ & Silt and silty clay ${ }^{(b)}$ & Absent \\
\hline MD01-2409 & $41^{\circ} 33.65^{\prime}$ & $141^{\circ} 52.06^{\prime}$ & off Shimokita & 975 & 44.67 & & & Absent \\
\hline MD01-2412 & $44^{\circ} 31.65^{\prime}$ & $145^{\circ} 00.25^{\prime}$ & off Shiretoko & 1225 & 58.11 & $106^{(c)}$ & Diatomaceous clay ${ }^{(\mathrm{c})}$ & Present \\
\hline MD01-2421 & $36^{\circ} 01.41^{\prime}$ & $141^{\circ} 46.79^{\prime}$ & off Kashima & 2286 & 45.84 & $32^{(\mathrm{d})}$ & Silty clay ${ }^{(\mathrm{e})}$ & Present \\
\hline $\mathrm{MD} 01-2422$ & $32^{\circ} 08.65^{\prime}$ & $133^{\circ} 51.76^{\prime}$ & off Kochi & 2737 & 47.88 & $23^{(f)}$ & Silt and clay $(\mathrm{s})$ & Present \\
\hline MD01-2423 & $32^{\circ} 50.10^{\prime}$ & $133^{\circ} 45.87^{\prime}$ & off Kochi & 1042 & 36.36 & & & Possibly present* \\
\hline
\end{tabular}

*This core has not been investigated for lithology. But the expulsion of soupy sediment from the recovered core suggests the presence of soupy disturbance. (a) KH-79-3 L 3, Oba et al., 1991, (b) KT 94-15 PC-9, Okumura et al., 1996, (c) HO76 P1, Shimada et al., 2000, (d) MR97-04 St. 3, Oba et al., 1999. (e) MR97-04 St. 3, Murayama et al., 1999, (f) KT-89-18 P-4, Murayama et al., 1991, (g) KT-89-18 P-4, Oba and Yasuda, 1992. 


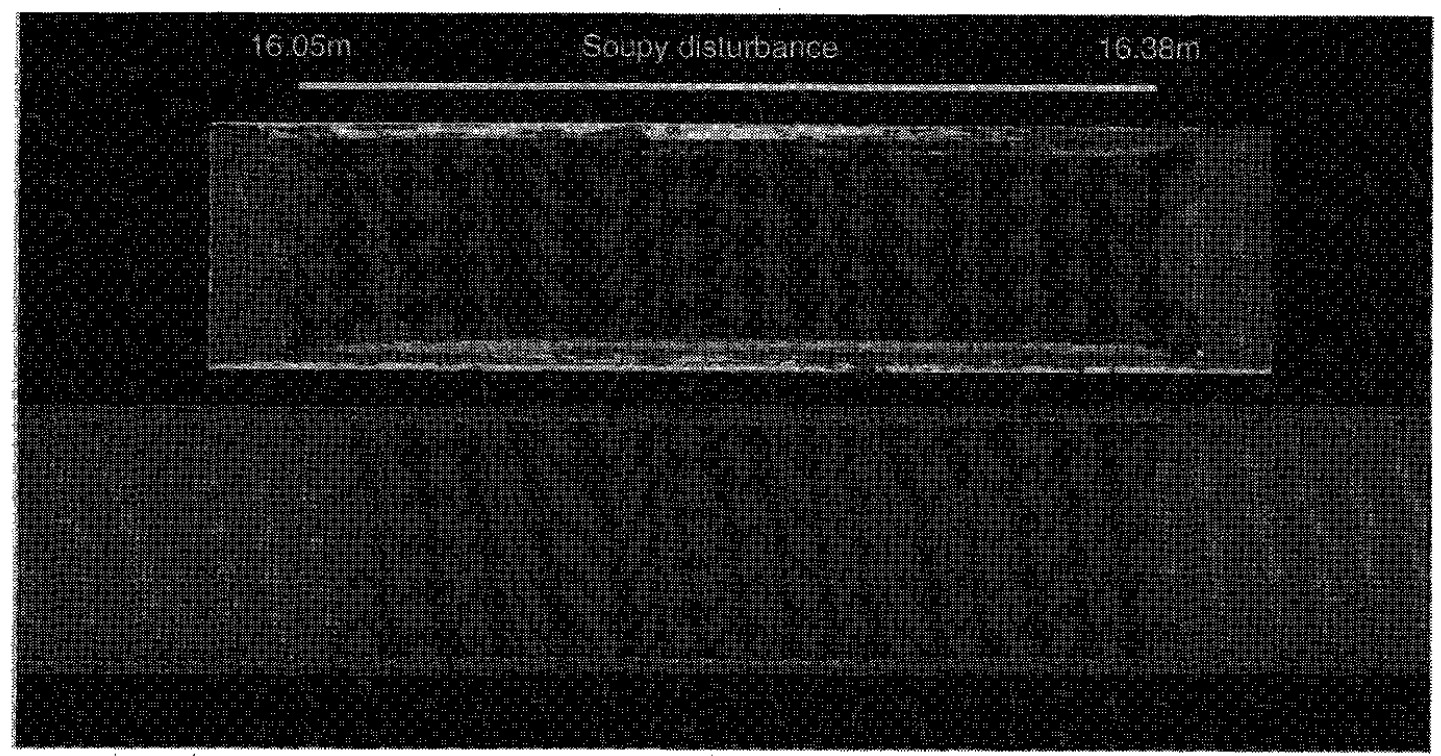

Fig. 2 Photograph and tomographic image of the soupy disturbance appeared between $16.05 \mathrm{~m}$ and $16.38 \mathrm{~m}$ deep in Core MD01-2422 from off Kochi. The photograph image was scanned using a digital image scanner system (GEOTEK Co. Ltd.) on the MultiSensor Core Logger (MSCL). The tomographic image was obtained by scanogram method (radiation energy; $120 \mathrm{kV}, 100 \mathrm{~mA}$, slicing; $2 \mathrm{~mm}$, Filter No. 0 ) using a X-ray CT scanner system PRATICO, Hitachi Medico Co. Ltd., Japan. Dark Shadow in tomographic image indicates the presence of low density materials such as water.

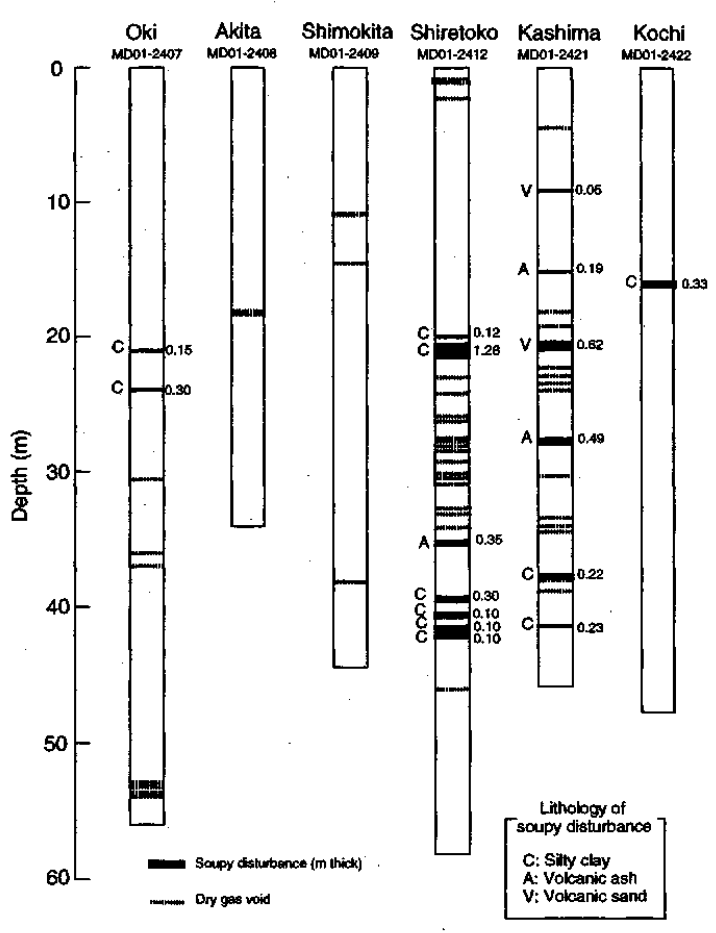

Fig. 3 Depth distributions of soupy disturbance and dry gas void.
の成因として，海水と堆積物の流扎込みを考えることは 困難である。

ガスハイドレートを含むコアにおいて，液状化した擾 乱層がみられる。これはガスハイドレートの分解により 生じた水と八イドレートガスの流出による摄乱構造であ ると考えられている(Paull et al., 1996)。ガスハイド レートの分解はガスの発泡によるコア内の圧力上昇上八 イドレート吸熱分解反応による低温下を伴う。本航海の スープ状醩乱層準で観察された現象は; この上うなガス ハイドレート分解に起因する現象と良く一致する。今回 スープ状婹乱層の出現したコアの堆䡠物は Field and Kvenvolden (1985) の相平衡図上でガスハイドレート が安定に存在しうる範囲（堆積物表層から深度 $100 \sim 700$ m）にある。したがって，本航海で認められたスープ状 擾乱層はガスハイドレート起源である可能性が高い。し かし, 本航海では, コア温度と間隙水筥濃度の測定を行 わなかったため，ガスハイドレート起源であることを実 証するには至らなかった。

日本近海においてこれまでピストンコアやグラビ ティーコアを用いたコアリングが行われてきたが，スー プ状擾乱層は報告されていない。記載の見落としである 可能性す考えられるが, 本研究で示されたように $20 \mathrm{~m}$ 以浅ではスープ状擾乱層が頻繁には出現しないため（お 
そらく 20 以浅ではメタン酸化が活発であるため)，従来 のコアリングではコア長が短く，スープ状擾乱層層準に 達しなかった可能性が考えられる。

\section{5. 意義}

ガスハイドレートとは水分子が水素結合により結びつ いたできた籠状構造中にガス分子が取り込まれた構造を 持つ固体の結晶の総称であり (Hand et $a l,, 1974$ ), 有機 物に富む大陸棚〜大陸斜面の堆積物にはガスハイドレー トが大量に存在している可能性が指摘されている (Kvenvolden, 1988 ; 松本ほか, 1994)。

我が国の周辺の海域においても奥尻海嶺 (ODP，Leg 127)，四国沖南海トラフ(ODP Leg 131)，遠州灘沖 (基礎試錐「南海トラフ」) において実際にガスハイド レート試料が採取されたほかに, 反射法音波探查記録の 海底面疑似反射面 (BSR) の位相解析に基づきガスハイ ドレートの分布が推定された（例えば，佐藤，2001）。 もし，本航海において確認されたスープ状䁓乱層がガス ハイドレート起源であるとすると, 日本近海ではガスハ イドレートはこれまで考えられてきた範囲 (Fig. 1)よ りあ広範囲に分布していることになる。このことを実証 してゆくためには, 日本近海のスープ状擾乱層の成因を 検証してゆくことが必要である。今後，日本近海で長尺 ピストンコアリングを行う際には, ガスハイドレートの 出現の可能性を考虑にいれて船上分析の準備を行うこと が必要である。

\section{謝 ·辞}

IMAGES VII-WEPAMA Leg 2 航海における Marion Dufresne 乗船研究者一同には本研究の遂行にあたりご 協力いただいた。佐藤幹夫氏（産業技術総合研究所 [以 下，産総研]）には草稿を読んでいただき，多くの有益 な助言をいただいた。渡部芳夫博士（産総研），松本良 教授 (東京大学), 棚橋学博士 (産総研) にはガス八イ ドレートの認定に関して適切なご意見をいただいた。池 原研博士（産総研）には知床沖の海底地形と音波探查記 録から知床沖コア周辺の遊離ガス層の存在を示唆してい ただいた。CT スキャン画像の撮影にあたっては安田尚 登教授, 多田井修博士, 佐川優子氏 (高知大学海洋コア 研究センター）にお世話になった。さらに，匿名の查読 者からは有益なコメントをいただいた。以上のかたがた
にお礼申し上げる。

\section{文献}

Field, M.E. and Kvenvolden, K.A., 1985: Gas hydrates on the northern California margin. Geology, 13, 517-520.

Hand, J.H., Katz, D.L. and Verma, V.K., 1974 : Review of gas hydrates with implication for ocean sediments. In Kaplan, I.R. ed., Natural Gases in Marine Sediments, 179-194, Plenum Press.

Kvenvolden, K.A., 1988 : Methane hydrates-A major reservoir of carbon in the shallow geosphere? Chem. Geol., 71, 41-51.

松本 良・奥田義久・青木 豊, 1994 ：メタンハイド レート 21世紀の巨大天然ガス資源．日経サイェンス 社.

村山雅史 ·岩倉央和 - 松本英二 - 中村俊夫 · 安田尚登 · 岡村 真・平 朝彦, 1991 : 過去30,000年間における 北西太平洋の深層循環、日本第四紀学会講演要旨集, 21, 114-115.

村山雅史 - 山根雅之 - 岡俊太郎 - 大場忠道 - 山本浩文 · 山内守明, 1999：MR 97-04 次航海で得られた海底コ 乃の概要. 海洋科学技術センタ一試験研究報告, 39, $85-94$.

Oba, T., Kato, M., Kitazato, H., Koizumi, I., Omura, A., Sakai, T. and Takayama, T, 1991 : Paleoenvironmental changes. in the Japan Sea during the last 85000 years. Paleoceanogr., 6, 499-518.

大場忠道・安田尚登，1992：黒潮域に招ける最終水期以 降の環境変動. 第四紀研究, 31, 329-339.

大場忠道 - 村山雅史 - 山内守明 - 山根雅之 - 岡俊太郎 山本浩文, 1999：「みらい」MR 97-04 次航海で採取 された海底コア中の有孔虫殼の酸素同位体比. 海洋科 学技術センター試験研究報告, 39, 41-45.

奥村 智 - 南川雅男 - 大場忠道 - 池原 研, 1996：日本 海秋田沖の 2 本の海底コアの酸素・炭素・窒素同位体 比に基づく古環境解析. 第四紀研究, 35，349-358.

Paull, C.K., Matsumoto, R., Wallace, P. et al., 1996 : Proceedings of the Ocean Drilling Program, Initial Reports, 164, Texas A\&M Univ., College Station, TX.

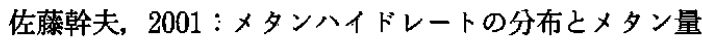
及び資源量. 日本エネルギー学会誌，80，1064-1074. 島田智恵子・村山雅史・青木かおり・中村俊夫 ·長谷川 四郎・大場忠道, 2000 : 珪藻分析に基づく南西オホー ツク海の完新世古海洋環境復元. 第四紀研究, 39 , 439-449. 